\title{
How an Ugly Duckling Became a Swan
}

\author{
COMMUNICATION CORNER
}

\author{
by Philip Yaffe
}

\section{Editor's Introduction}

The thrust of the Communication Corner is to offer step-by-step advice to help you become a better writer and speaker. However, perhaps the best way to get started is with some encouraging background. This first essay tells how Philip Yaffe went from being a very poor writer and speaker to being a recognizably good one, almost despite himself.

Practical, step-by-step advice to help you do the same will begin next month. 


\title{
How an Ugly Duckling Became a Swan
}

\author{
COMMUNICATION CORNER
}

\section{by Philip Yaffe}

Have you ever noticed that books about effective writing talk only about effective writing, and books about effective public speaking talk only about public speaking, and never the twain meet?

This is a mistake. Writing and speaking are intimately related and should be considered together, rather than as distinct disciplines. Trying to learn them separately almost guarantees that you will learn neither of them well.

I am a perfect example of this truism.

Over the past 40-plus years, I have frequently been told that I am an exceptionally good writer and speaker, by teachers, friends, colleagues, and clients. But I wasn't always a good writer and speaker; in fact, I used to be a very bad writer and speaker.

So what happened to bring about this monumental change? Basically, university.

When I was growing up in Los Angeles, I was a very unusual kid. Like all youngsters in the 1950s, I loved surfing. But I also loved school, even to the point of complaining about holidays because I would be deprived of the joy of going to class.

I was especially fond of math and science; I never really thought about writing. However, when I went from primary to secondary school, I quickly realized that writing would become increasingly important. So being the bizarre kid I was, I decided to teach myself how to do it.

I did two basic things. On my own:

- I studied English grammar to the point that I knew it backwards, forwards and upside down. I could put together the most involved, convoluted, grammatically flawless sentences imaginable. 
- I also studied vocabulary. Classically, I challenged myself to learn-and use-five new words a day. I very rapidly gained a vocabulary far above the norm for my age.

I then put the two things together and decided that the essence of good writing was intricate sentences liberally sprinkled with sophisticated vocabulary. This was how I wrote themes, essays, book reports, etc. As I expected, I always got top marks.

During my last year in secondary school, I submitted one of these arcane masterpieces, which came back with the traditional "A." However, this time there was a note saying: "Philip, you have such interesting, original ideas. Why do you bury them under such complex, convoluted language? Next year when you go to university, I suggest that you take a one-term course in basic journalism to learn how to simplify your writing."

I had no particular interest in journalism, or even in writing. However, I did have particular respect for this teacher, so I decided to follow his advice. At university I enrolled in a first-term journalism class.

This was when everything changed.

At the end of the second week, the professor assigned us a short article to write. I confidently handed it in. But when it came back, instead of the traditional " $A$ " grade, it had a " $C$." I was severely shaken; this was the first " $C$ " I had ever seen. I worked rather harder on the second assignment, which also came back with a "C."

I told myself that this just didn't make any sense, so for the third assignment I put my heart and soul into the work. This time it did not come back with a "C." It came back with a "D."

Now I was really shaken, and scared. I began actually listening to what the professor was saying. Finally, I realized that writing clearly and concisely was much more difficult than the socalled "sophisticated" writing I had been doing.

Recognizing "simple" writing to be a challenge, I really concentrated on what I was doing, and my grades started to rise. Not just in journalism. Even better, I began getting complimentary notes from professors in other classes on how much they appreciated my new, crisp, clean writing style. In other words, what I was learning as basic journalism was generating positive results in my other academic pursuits.

For example, in a political science class I once turned in an essay that I knew went directly counter to the professor's opinion. In an English literature class I turned in a review of one of the professor's favorite books, which I trashed. In both cases the reaction was the same. I got 
an "A." While neither professor was totally convinced, they both said that I had presented my arguments in such a clear, compelling manner, they simply couldn't be dismissed.

Having discovered journalism, I subsequently joined the daily student newspaper, rose through the ranks, and in my final year became editor-in-chief. I also began tutoring other students in writing. In the mid-1960s, universities didn't have writing centers to help floundering students. About the only way to resolve writing problems was through private tuition.

I remember one case in particular. A girl came to me with a note from a professor: "Young lady, I advise you either to drop my class immediately or prepare to fail it." Obviously she was bright enough; after all she was a student at UCLA (University of California, Los Angeles). So where was the problem? I read a couple of her essays that had gotten such poor marks. There was no question that she had a lot of interesting things to say. Equally, there was no question that she was saying them very badly.

It quickly became apparent where the problem lay. She simply was not fully using one of the fundamental principles of good writing, because she thought that consistently applying it was just too much trouble. It took a couple of sessions to convince her that it wasn't too much trouble-in fact it was crucial. Her writing immediately began to improve. At the end of the term, not only didn't she fail the class, she had pulled her grade all the way up from a certain "F" to a solid "B."

I am not saying that to be a good writer in general, you should study journalism first. However, because it was the antithesis of the poor writing I had been doing, journalism gave me a flying start. Over the past four decades I think I have added some insights into good writing (and speaking) that I didn't learn from journalism. Or at least I have made explicit certain key ideas that previously were implicit, and therefore poorly applied.

I subsequently applied what I had learned about good writing to public speaking. And the rest, as they say, is history.

Today, as when I was a student, my passion is still mathematics and science. My career path has taken me in a somewhat different direction. But I don't regret it; it's been quite a journey.

The moral of the story? There are in fact two of them:

- Good writing-and by extension good speaking-are fundamentally important skills, in academia and beyond.

- Beware of teachers bearing advice; it could radically change your life. 


\section{Mathematical Magic}

I would like to conclude this introduction to the Communication Corner with a magic trick based on a mathematical formula. I came across this trick when I was a teenager. At that time I was in love with mathematics and intrigued by magic; this trick combined both.

Anyone can do the trick; it is only necessary to apply the formula. The difficulty was, I wanted to know why it works. As often as I tried, I just couldn't figure it out. I didn't become obsessed by it; however, every time I showed it to someone, I made another try at resolving the mystery.

Then one day it occurred to me. Maybe there was something about the instructions that kept leading me down a false path. Sure enough, there was. Once I had caught and disposed of this red herring, everything fell into place. Understanding how it works became child's play.

Writing and speaking clearly and concisely is a leitmotiv of the Communication Corner, so let me put myself to the test. Writing instructions without supporting diagrams or photos is a real challenge. Here are the instructions for the trick. Please let me know if you can easily and successfully follow them-or what improvements you think might be needed to do it better.

\section{The Setup}

Take an ordinary deck of 52 cards. Thoroughly shuffle them. Then divide the deck as follows.

- Deal out the first card of the pack face up on a table. Starting from the value of that card, deal out more cards face up on top of it up to the value of thirteen. Example: You turn over a seven. For the next card you deal out, you say eight, then nine, then 10, then 11, then 12, then 13. Turn the pile face down. This is the first pile.

- Now make a second pile the same way, i.e. from the cards left in your hand deal out a card face up. Starting from the value of this card add cards until you get to 13. Turn this second pile face down. Continue making piles until the cards in your hand are exhausted.

Two caveats.

- When starting each new pile, if the card you turn over is a picture card, bury it somewhere in the deck. Start a pile only with values one (ace counts as one) through ten. Never start a pile with a picture card.

- When trying to make the last pile, if you don't have enough cards left, just keep these cards in you hand; don't put them down on the table.

After you have finished dividing the deck, you will probably have from four to seven face-down piles on the table, plus the cards remaining in your hand. While your back is turned, ask 
someone to move the piles around as much as he wishes, so that you could not possibly know which pile is which.

Turn around and ask him to remove all but three piles and give you the cards.

Finally, ask him to turn over the top card of any two of the remaining three piles. You will apply the formula to tell him the value of the top card of the third pile. He will be amazed when you do.

\title{
The Formula
}

Here's how you apply the formula.

First, from the cards in your hand count out on to the table the value of one of the visible cards on top of a pile, then count out the value of the second visible card.

Next, count out another 10 cards.

Finally, count out the number of cards you still have left in your hand. This number of cards will be the same as the value of the top card of the third pile.

You of course do all of this counting in your head, not aloud. You then announce the value of the third card. Just listen to the oohs and aahs when it is turned over and you are proved correct.

You can do this as many times as you want; it always works. But why? Think about it for a while. If you can't figure it out, return to the Communication Corner next month to find out.

\begin{abstract}
About the Author
Philip Yaffe was born in Boston, Massachusetts, in 1942 and grew up in Los Angeles, where he graduated from the University of California with a degree in mathematics and physics. In his senior year, he was also editor-in-chief of the Daily Bruin, UCLA's daily student newspaper. He has more than 40 years of experience in journalism and international marketing communication. At various points in his career, he has been a teacher of journalism, a reporter/feature writer with The Wall Street Journal, an account executive with a major international press relations agency, European marketing communication director with two major international companies, and a founding partner of a specialized marketing communication agency in Brussels, Belgium, where he has lived since 1974. He is the author of more than 20 books, which can be found easily in Amazon Kindle.
\end{abstract}


DOI: $10.1145 / 3019074$ 